\title{
IDENTIFICATION OF AN ALKALINE PROTEASE PRODUCING BACTERIUM ISOLATED FROM PANJIN RED BEACH, CHINA
}

\author{
YUAN, Y. ${ }^{1}-$ GAO, J. Y. ${ }^{2}$ - DU, L. Q. ${ }^{2}-$ LI, X. M. ${ }^{1}-$ LI, Y. Y. ${ }^{1}-$ WANG, L. L. ${ }^{1}-$ BU, N. ${ }^{1 *}-$ \\ MA, L. J. ${ }^{1 *}$ \\ ${ }^{1}$ College of Life Science, Shenyang Normal University \\ No. 253 Huanghe North Street, Shenyang, Liaoning 110034, China \\ ${ }^{2}$ College of Life Science, Wuhan University, Wuhan 430072, China \\ *Corresponding authors \\ e-mail:malianju@163.com,buning60@sohu.com \\ (Received $1^{\text {st }}$ Mar 2019; accepted $1^{\text {st }}$ May 2019)
}

\begin{abstract}
Extremophilic bacteria surviving in extreme environmental conditions possess the special abilities to adapt adverse environment. There are very high salinization and alkalinization contents in Panjin Red Beach's soil. A productive alkline protease strain HHT597 was isolated from the soil samples and identified as Bacillus altitudinis based on the 16s rDNA sequence. The HHT597 strain was characterized as a gram positive, rod-shaped bacterial strain with flagellum. The optimum temperature for protease activity by the strain HHT597 was $60^{\circ} \mathrm{C}$. There was a broad pH active range of protease from 7.0-11.0 with having optima $\mathrm{pH}$ 9.0. The media containing $2.0 \%$ glucose and $1 \%$ yeast extract as carbon and nitrogen sources could improve protease activity. The strain HHT597 could degrade casein, hemoglobin (HGB) and albumin (ALB) protein. The results indicated that the strain HHT597 might be potential for biotechnological applications.
\end{abstract}

Keywords: extreme environment, isolation, 16S rRNA gene, identification, Bacillus

\section{Introduction}

Proteases, which catalyze proteolysis by performing cleavage of peptide bonds, are widely used industrial enzymes, accounting for more than $65 \%$ of the total worldwide sale of the enzymes (Rao et al., 1998; Shankar et al., 2011; Annamalai et al., 2014). Proteases include alkaline, acid, thiol and metallo proteases. Among these categories of proteases, alkaline proteases are a class of extracellular enzyme that performs proteolysis and have wide applications as industrial catalysts in various of industries and research laboratories, which could be used in enzymatic peptide synthesis, biotransformation reactions, detergent, surfactants, food processing, diagnostic reagents, preparation of organic fertilizers, silver recovery from used X-ray film and wastes treatment (Kalisz, 1988; Anwar and Saleemuddin, 1998; Shah et al., 2010; Rathod and Pathak, 2016; Hakim et al., 2018). A wide range of sources was found to produce alkaline protease such as bacteria, molds, yeasts, certain insects or mammalian tissues (Mabrouk et al., 1999; Kumar et al., 2014). Bacteria producing 
alkaline protease are the most important approach relative to plants, animal, and fungus because of their extracellular nature, high yield of production, limited space, convenient cultivation and feasibility to genetic manipulation (Breithaupt, 2001; Selvamohan and Sherin, 2010).

With previous studies gaining a better understanding of the physical, chemical and biological properties of alkaline proteases, researchers nowadays focus more on searching for alkaline proteases with specificities such as high temperature and $\mathrm{pH}$ tolerance. Active ranges of temperatures of alkaline (serine) proteases were $35^{\circ} \mathrm{C}-$ $80^{\circ} \mathrm{C}$ and $\mathrm{pH}$ was 7-12 (Rao et al., 1998). Morozkina et al. (2010) reported that the extremophiles could produce extremozymes. Through the long term of natural selection, extremophilic bacteria possess the special abilities associated tightly with their structures, physiological mechanisms, genetic characteristics and biochemical pathways. For example, they can produce extracellular proteases. At high $\mathrm{pH}$ and temperatures, there were remarkable activity and stability in alkaline protease produced by marine bacteria (Arastoo and Zahra, 2013). Therefore, extreme environments, in particular, marine environments are a valuable approach for bacteria producing microbial enzymes (Mirete et al., 2016).

Panjin Red Beach which locates in Liaoning, China, is a famous wetland landscape covering an area of $133.33 \mathrm{~km}^{2}$ on a flat and broad terrain (Wang et al., 2011). Years of marine corrosion leads to the soil a sandy, humid and heavy texture with a high level of salinization and alkalinization. The inartificial edatope creates a unique ecosystem that provides native habitats for variety of halophilic and basophilic microorganisms. Therefore, it is likely to find functional strains that are adaptation to saline-alkali environment. Our research focused on isolating and identification bacteria producing alkaline protease with protease activity in the natural salinealkaline soil of the Red Beach.

\section{Materials and Methods}

\section{Isolation of Bacterial Strain Producing Alkaline Protease}

Five representative plots were selected during September 2017 in Panjin Red Beach. Soil samples, five soil cores $(5 \mathrm{~cm}$ diameter) were collected in triplicate from the topsoil $(0-15 \mathrm{~cm})$ in each sampling site and mixed evenly, then placed in aseptic polyvinyl chloride soil bag.

Soil samples $(10 \mathrm{~g})$ collected were suspended in $90 \mathrm{~mL}$ of sterile distilled water. After a serial dilution $\left(10^{-3}\right.$ to $\left.10^{-5}\right)$ of the soil suspension with sterile distilled water, $0.1 \mathrm{~mL}$ soil suspension was spread on selective agar plates and incubated at $37^{\circ} \mathrm{C}$ for 2 $\mathrm{d}$. The selective agent in the agar plates contained beef extract $0.3 \%(\mathrm{w} / \mathrm{v})$, casein $1 \%$ $(\mathrm{w} / \mathrm{v}), \mathrm{NaCl} 1.5 \%(\mathrm{w} / \mathrm{v})$, agar $2 \%(\mathrm{w} / \mathrm{v})$. Ten plates were screened in soil samples and about 150 plates altogether were screened. The strain having the largest clear zone was selected by secondary screening for this study. 


\section{Identification of Bacteria Strain}

Bacteria strain was performed by Gram staining and biochemical tests such as methyl red test, V-P test, carbohydrate fermentation test and hydrogen sulfide production test following commonly used microbial identification manuals like Bergey's manual (Holt, 1994). Each treatment was conducted with three replicates.

The total genomic DNA of the bacteria strain was extracted and purified using Bacterial DNA Isolation Kit (Sangon Biotech Co., Ltd, China) according to maufacturer's instructions. The $16 \mathrm{~S}$ rDNA of the isolate was amplified through PCR reaction using the universal primers 27f (5'-AGAGTTTGATCATCCTGGCTCAG-3') and 1492r (5'-TACGGTTACCTTGTTACGACTT-3') synthesized by Sangon Biotech Co., Ltd (Shanghai, China). The PCR reaction process was as follows: $95^{\circ} \mathrm{C}$ for $5 \mathrm{~min}$, 35 cycles of $95^{\circ} \mathrm{C}$ for $1 \mathrm{~min}, 55^{\circ} \mathrm{C}$ for $1 \mathrm{~min}, 72^{\circ} \mathrm{C}$ for $2 \mathrm{~min}$, and a final extension at $72^{\circ} \mathrm{C}$ for $10 \mathrm{~min}$. PCR product was sent to Sangon BiotechCo., Ltd (Shanghai, China) for sequencing. The similarities of the sequence were identified using online EzBioCloud database (https://www.ezbiocloud.net/). Construction of phylogenetic tree was carried out using MEGA 7 (Kumar et al., 2016).

\section{Enzyme Assay Estimation}

Alkaline protease activity was determined by using casein as a substrate by method of Yang and Wang (1999). One unit of protease activity was defined as the amount of the enzyme that produces $1 \mu \mathrm{g} / \mathrm{mL} / \mathrm{min}$ of tyrosine equivalent under the assay conditions.

\section{Optimum Conditions for Protease Activity}

Optimum Temperature and $\mathrm{pH}$ : Preheat $2.0 \%$ casein solution for $5 \mathrm{~min}$ by water bath at temperature ranging from $10^{\circ} \mathrm{C}$ to $80^{\circ} \mathrm{C}$. Mix $1 \mathrm{~mL}$ of each casein solution with $1 \mathrm{~mL}$ preheated crude protease solution and water bath at $40^{\circ} \mathrm{C}$ for $10 \mathrm{~min}$, then end the reaction with $5 \mathrm{~mL}$ TCA solution. The basal media was adjusted to seven different $\mathrm{pH}$ ranging 6.0-12.0. The seed culture $(1.0 \% \mathrm{~V} / \mathrm{V})$ was inoculated to each $150 \mathrm{~mL}$ liquid medium and was carried out at $37^{\circ} \mathrm{C}, 160 \mathrm{rpm}$ for $2 \mathrm{~d}$. Enzyme assay determination was as stated above.

Carbon and Nitrogen Sources: $2.0 \%$ each of glucose, maltose, sucrose and lactose was added in the basal media to investigate the effects of different carbon sources. To observe the effects of various nitrogen sources on protease activity, $1.0 \%$ each of beef extract, peptone, yeast extract, sodium nitrate, ammonium nitrate and ammonium chloride was added to the basal media. Fermentation was carried out under optimum temperature and $\mathrm{pH}$ at $130 \mathrm{rpm}$ for optimum period. Enzyme assay determination was as stated according to the method described above.

Substrate Specificity Assay: Prepare 2\% (w/v) of each casein, gelatin, hemoglobin (HGB), albumin (ALB) solution as substrate. Mix $1 \mathrm{~mL}$ substrate solution with $1 \mathrm{~mL}$ preheated the crude protease solution and water bath at $40^{\circ} \mathrm{C}$ for $10 \mathrm{~min}$, then end the reaction with $5 \mathrm{~mL}$ TCA solution. Enzyme assay determination was as already mentioned. 


\section{Statistical analysis}

All data were analyzed according to Duncan's multiple range tests using the SPSS 11.0 software package.

\section{Results and Discussion}

\section{Isolation, Screening and Identification of Strain HHT597}

Eight isolates from soil samples showed clear zone around bacterial colonies on the selective medium, indicating that these strains can produce extracellular alkaline protease. These eight strains were named for from HHT591 to 598. Finally, bacterium strain HHT597 was chosen for further study based on the intensity of clear zone.

The strain HHT597 was characterized as a gram positive, rod-shaped bacterial strain with flagellum (Figure 1A). Colony morphology was faint yellow, round, marginal tidy, dry surface (Figure 1B, C).
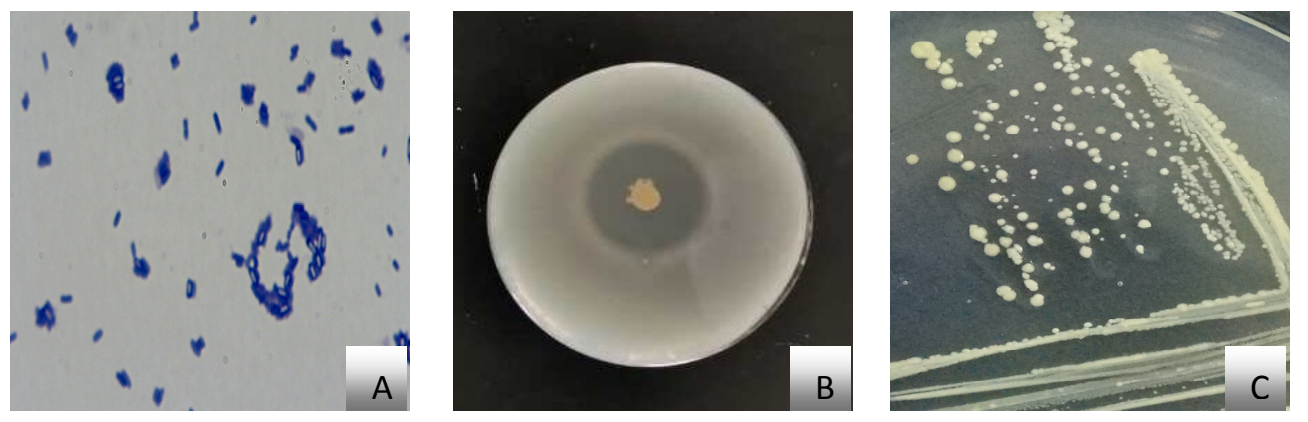

Figure 1. The colony morphology (A, B) and Gram stain (C) of bacteria strain HHT597

Biochemical characteristics were listed in Table 1. Based on the morphological and biochemical characteristics, isolate HHT597 was identified as Bacillus sp. Among all the alkaolphilic microorganisms, Bacillus spp. is the most predominant and a prolific source of alkaline proteases (Kumar and Takagi, 1999).

Table 1. Biochemical characteristics of strain HHT597

\begin{tabular}{c|c|c|c|c|c|c}
\hline Glucose & Lactose & Acid production & Gas production & Voges Proskauer & Methyl red & $\mathbf{H}_{2}$ S production \\
\hline+ & - & - & + & + & + & + \\
\hline
\end{tabular}

To carry out the 16S rDNA gene sequencing analysis, the genome of strain HHT597 was used for PCR amplification of $16 \mathrm{~S}$ rDNA. The molecular weight of PCR product of strain HHT597 was corresponding to $1500 \mathrm{bp}$ of the DNA marker and the amplification was successful. The DNA sequence of 1456 bp product was uploaded to EzBioCloud database for phylogenetic identification and comparison. Phylogenetic tree was 
constructed based on neighbour-joining statistical algorithms. According to phylogenetic tree (Figure 2), the strain HHT597 were clustered with Bacillus altitudinis strain G65 with high (99\%) 16S rDNA sequence similarity. The strain HHT597 was affiliated to the genus Bacillus.

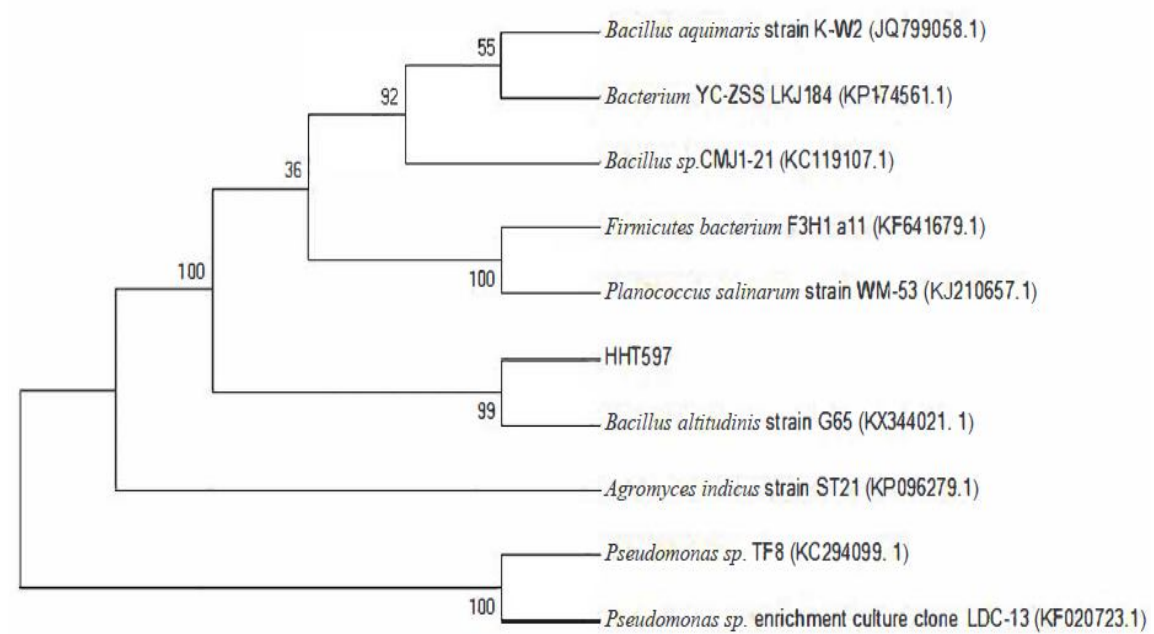

Figure 2. Phylogenetic tree of HHT597 and B. altitudinis strain G65 with other B. species

\section{Effects of Temperature and $\mathrm{pH}$ on Protease Activity}

Generally, the protease activity is easily decreased by high temperature. The temperature optima of protease depended on the bacterial species (Iqbal et al., 2018). In the present study, the alkaline protease activity first gradually increased then gradually decreased with increasing temperature (Figure $3 a$ ).
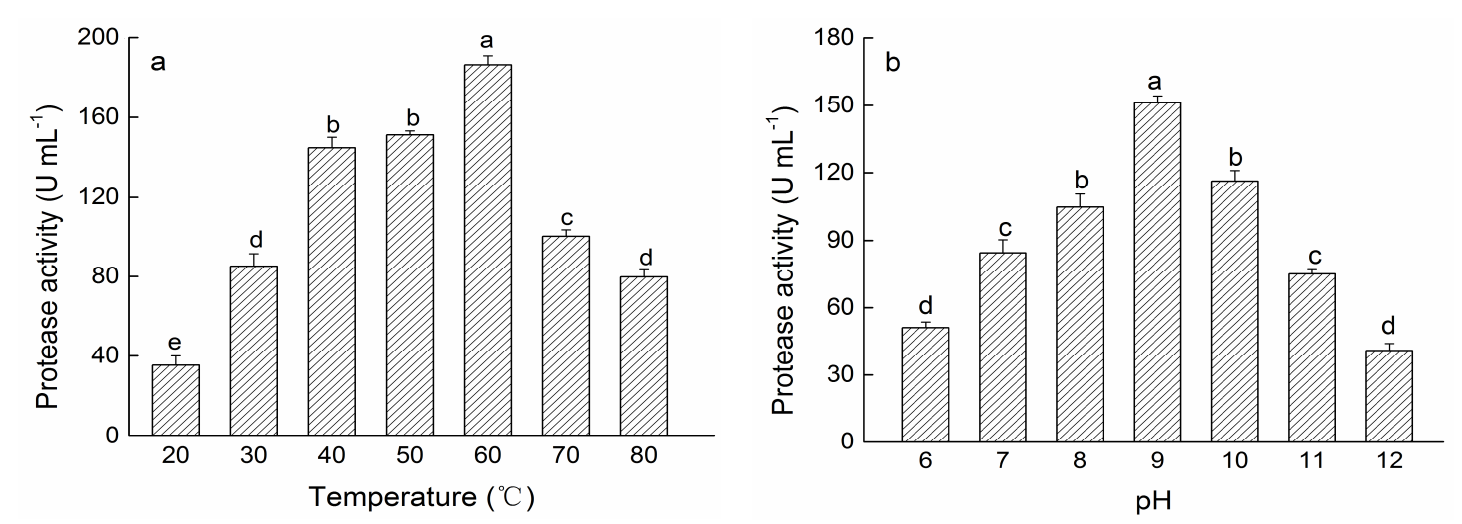

Figure 3. Effects of temperature (a) and $p H$ (b) sources on alkaline protease activity

The optimum temperature of protease activity produced by strain HHT597 was $60^{\circ} \mathrm{C}$ and protease activity reached $186.35 \mathrm{U} / \mathrm{mL}$. When temperature was up to $70^{\circ} \mathrm{C}$, the protease activity began gradually to decrease. The results indicated that the protease 
produced by the strain HHT597 could work at high temperatures. Nevertheless, almost similar protease activity was found at $40-50^{\circ} \mathrm{C}$ (Hakim et al., 2018).

Many enzymatic processes are strongly influenced by the pH (Ellaiah et al., 2002; Hakim et al., 2018). In the present study, the $\mathrm{pH}$ active range of protease was from 7.0 to 11.0. The optimum $\mathrm{pH}$ for alkline protease activity was 9.0, and the protease activity was $151.21 \mathrm{U} / \mathrm{mL}$ (Figure 3b). Rao et al (1998) reported that $\mathrm{pH}$ optima of alkaline protease in commerce were from 8.0 to 12.0 .

\section{Effects of Carbon and Nitrogen Sources on Protease Activity}

The carbon and nitrogen sources used in the media highly influenced production of alkaline protease (Hakim et al., 2018). The media containing glucose at $2 \%$ was the most favorable source supported the highest alkaline protease production compared to other carbon sources (Table 2). The results were similar with other reports (Ellaiah et al., 2002; Hakim et al., 2018). Among the different nitrogen sources studies, $1 \%$ yeast extract was the most benefit for alkaline protease production (Table 2), which is consistent with previous results of $B$. subtilis AKAL7 (Hakim et al., 2018) and B. sp MA6 (Azad and Hoq, 2000). However, the strain HHT597 could not use inorganic nitrogen compounds as nitrogen sources.

Table 2. Effects of carbon source, nitrogen source and substrate on alkaline protease activity

\begin{tabular}{c|c|c}
\hline \multicolumn{2}{c|}{ Treatment } & Protease activity (U/mL) \\
\hline \multirow{3}{*}{ Carbon source } & Glucose & $89.26 \pm 1.73 \mathrm{a}$ \\
& Maltose & $79.37 \pm 2.38 \mathrm{~b}$ \\
& Sucrose & $35.43 \pm 1.2 \mathrm{c}$ \\
& Lactose & $78.34 \pm 1.34 \mathrm{~b}$ \\
\hline \multirow{2}{*}{ Nitrogen source } & Beef extract & $117.26 \pm 4.16 \mathrm{~b}$ \\
& Yeast extract & $186.24 \pm 8.56 \mathrm{a}$ \\
& Peptone & $109.32 \pm 6.52 \mathrm{~b}$ \\
& Ammonium nitrate & - \\
\hline Substrate & Sodium nitrate & - \\
\hline & Ammonium chloride & $136.63 \pm 7.65 \mathrm{a}$ \\
& Casein & - \\
& Gelatin & $112.06 \pm 4.31 \mathrm{~b}$ \\
& Hemoglobin & $108.63 \pm 2.62 \mathrm{~b}$ \\
\hline
\end{tabular}

The different letters indicate significant differences at $P<0.05$

\section{Optimum Substrate on Protease Activity}

Casein, HGB, AHL and gelatin was used as substrate to detect the protease degradation ability, respectively. Among four substrates, casein was the most appropriate substrate and the maximum protease activity was $136.63 \mathrm{U} / \mathrm{mL}$ (Table 2). HGB and AHL could also be the substrate of alkline protease extracted from HHT597. However, gelatin was not used as the protease substrate. 


\section{Conclusion}

A productive alkline protease, gram positive bacterial strain of the genus Bacillus was isolated from the soil samples of Panjin Red in China and identified as B. altitudinis strain HHT597. The optimum temperature for maximum protease activity produced by the strain HHT597 was $60^{\circ} \mathrm{C}$. There was a broad $\mathrm{pH}$ active range of protease from 7.0-11.0. The optimum carbon and nitrogen sources for protease activity produced by the strain HHT597 was $2 \%$ glucose and $1 \%$ yeast extract, respectively. The strain HHT597 could degrade casein, HGB and AHL protein. The research results showed that the strain HHT597 might be potential for industrial applications.

Acknowledgements. This work was supported by Shenyang city Science and Technology plan (F16-2051-50), Major incubating project of Shenyang Normal University (ZD201705) and Liaoning Province Science and Technology Plan Progect (No.2017208001).

\section{REFERENCES}

[1] Annamalai, N., Rajeswari, M. V., Balasubramanian, T. (2014): Extraction, purification and application of thermostable and halostable alkaline protease from Bacillus alveayuensis CAS5 using marine wastes. - Food Bioprod Process 92(4): 335-342.

[2] Anwar, A., Saleemuddin, M. (1998): Alkaline proteases: a review. - Bioresour Technol 64: 175-183.

[3] Arastoo, B. D., Zahra, K. (2013): Screening and isolation of an organic solvent tolerantprotease from Bacillus sp. JER02: Activity optimization by response surface methodology. - J Mol Cataly B: Enzymatic 89: 15-23.

[4] Azad, A. K., Hoq, M. M. (2000): Production of alkaline serine protease by Bacillus sp. MA6. - Bangladesh J Microbiol 11(2): 143-149.

[5] Breithaupt, H. (2001): The hunt for living gold. - EMBO Rep 2(11): 968-971.

[6] Ellaiah, P., Srinivasulu, B., Adinarayana, K. (2002): A review on microbial alkaline proteases. - J Sci Ind Res 61: 690-704.

[7] Hakim, A., Bhuiyan, F. R., Qbal, A., Emon, T. H., Ahmed, J., Azad, A. K. (2018): Production and partial haracterization of dehairing alkaline protease from Bacillus subtilis AKAL7 and Exiguobacterium indicum AKAL11 by using organic municipal solid wastes. - Heliyon 4: e00646.

[8] Holt, J. G. (1994): Bergey's manual of determinative bacteriology. - 9th Edition, Lippincott Williams and Wilkins, Baltimore.

[9] Iqbal, A., Hakim, A., Hossain, M. S., Rahman, M. R., Islam, K., Azim, M. F., Ahmed, J., Assaduzzaman, M., Hoq, M. M., Azad, A. K. (2018): Partial purification and characterization of serine protease produced through fermentation of organic municipal solid wastes by Serratia marcescens A3 and Pseudomonas putida A2. - J Genet Eng Biotechnol 16: 29-37.

[10] Kalisz, H. M. (1988): Microbial proteinases. - Adv Biochem Eng Biotechnol 36: 1-65. 
[11] Kuma, C. G., Takagi, H. (1999): Microbial alkaline proteases: From a bioindustrial viewpoint. - Biotechnol Adv 17: 561-594.

[12] Kumar, R. S., Ananthan, G., Prabhu, A. S. (2014): Optimization of medium composition for alkaline protease production by Marinobacter sp. GA CAS9 using response surface methodology-A statistical approach. - Biocataly Agric Biotechnol 3: 191-197.

[13] Kumar, S., Stecher, G., Tamura, K. (2016): MEGA 7: Molecular evolutionary genetics analysis version 7.0 for bigger datasets. - Mol Biol Evol 33: 870-874.

[14] Mabrouk, S. S., Hashem, A. M., El-Shayeb, N. M. A., Ismail, A. M. S., Abdel-Fattah, A. F. (1999): Optimization of alkaline protease productivity by Bacillus licheniformis ATCC 21415. - Bioresour Technol 69(2): 155-159.

[15] Mirete, S., Morgante, V., González-Pastor, J. E. (2016): Functional metagenomics of extreme environments. - Curr Opin Biotech 38: 143-149.

[16] Morozkina, E. V., Slutskaya, E. S., Fedorova, T. V., Tugay, T. I., Golubeva, L. I., Koroleva, O. V. (2010): Extremophilic microorganisms: Biochemical adaptation and biotechnological application (review). - Appl Biochem Microbiol 46: 1-14.

[17] Rao, M. B., Tanksale, A. M., Ghatge, M. S., Deshpande, V. V. (1998): Molecular and biotechnological aspects of microbial protease. - Microbiol Mol Biol Rev 62(3): 597-635.

[18] Rathod, M. G., Pathak, A. P. (2016): Optimized production, characterization and application of alkaline proteases from taxonomically assessed microbial isolates from Lonar soda lake, India. - Biocatal Agric Biotechnol 7: 164-173.

[19] Selvamohan, T., Sherin, S. (2010): Optimization of protease production from Bacillus cereus using different substrates. - Plant Arch 10(2): 651-656.

[20] Shah, K., Mody, K., Keshri, J., Jha, B. (2010): Purification and characterization of a solvent, detergent and oxidizing agent tolerant protease from Bacillus cereus isolated from the Gulf of Khambhat. - J Mol Catal B-Enzym 67: 85-91.

[21] Shankar, S., Rao, M., Laxman, R. S. (2011): Purification and characterization of an alkaline protease by a new strain of Beauveria sp. - Process Biochem 46(2): 579-585.

[22] Wang, J. L., Huang, X. J., Zhong, T. Y., Chen, Z. G. (2011): Review on sustainable utilization of salt-affected land. - Acta Geogr Sin. 66: 673-684.

[23] Yang, S. S., Wang, J. Y. (1999): Protease and amylase production of Streptomyces rimosus in submerged and solid state cultivations. - Bot Bull Acad Sin. 40: 259-265. 